\section{Two into one goes slowly}

\section{Munich}

LIKE everything else in what was East Germany, the universities were undermined by the need to deal with Communist rule: at least outward accommodation to the Communist system, sometimes escalating to include the betrayal of colleagues to the secret police, was almost always required for even rudimentary academic success. As the leaders of the enjoys remarkable freedom from political intereference, take over the running of these decayed institutions, the task of sorting out what and who in the east deserve to be retained is proving difficult and divisive.

Universities enjoy an autonomy unique among public institutions in Germany. Although they are run by the state, universities benefit from a tradition of academic freedom bolstered by post- 1968 trators, not the state, sweeping powers over hiring.

The most politically active university organization in Germany, the newly christened "University Rectors' Conference" (HRK) - previously the West German Rectors' Conference - has included its recommendations for reform in a routine list of demands for more money. In uncharacteristically soft language, it called for the establishment of committees within eastern universities including "significant numbers of external scientists" to examine "structural and personnel West German university system, which reforms giving faculties and adminis- questions." Explaining the delicate approach, HRK president Hans-Uwe Erichsen says that HRK "wants to avoid any sort of politically motivated inspection". Although one may doubt the capability of the universities to purify themselves, he says, it is enough to include foreign researchers in the committees to ensure a fair evaluation. He admits that part of the reason for the careful approach is the fear of endangering university autonomy in the West. "We don't want to set a precedent," he explains, by allowing politicians to dictate hiring policy to university administrators. "What have been called 'partial and temporary' reductions in university autonomy in the past have often not been temporary at all." But in recommendations to be issued this week, the other political heavyweight in the university arena in Germany, the Wissenschaftsrat or science council, is expected to take a different line. According to chairman Dieter Simon, the Wissenschaftsrat will call for the temporary establishment of scientific committees to make binding recommendations to the governments of the eastern Länder (states) on how to reform universities.

These committees would be extremely powerful, having the ability to augment present university faculties or recommend entirely new structures. To ensure that old-boy networks are dismantled, the plan calls for each committee to include members exclusively from western Germany, foreign countries, and other eastern
Länder but not from local universities.

Simon expects the plan to be controversial. "Professors at these universities will be understandably critical," he admits, "because they were muzzled before by the state. To them, this just looks like a different style [ of repression]." But he argues that the loss of autonomy is the price that must be paid to improve both the scientific quality and the moral standing of the universities.

Simon stresses that the plan can work only if the federal and Länder governments provide more money to attract people to new posts in eastern German universities, a demand supported by HRK. Professors in the east still earn as little as one-half to one-fifth of the salaries of their counterparts in the west.

The downside to the plan, Simon recognizes, is that it does nothing to protect those who are politically untainted but whose talents are not far above average. For them, Simon admits unhappily, there is no solution as yet.

The problem of reforming the universities in the east is so daunting that many western leaders, including Erichsen, cling to statistics that show that up to two-thirds of the professors at universites in eastern Germany will retire in the next ten years, ensuring a certain degree of selfpurification. But Simon criticizes this optimism, saying that there are plenty of younger people who are badly compromised. Precedents set in West Germany indicate that a faculty member forced unwillingly out of a position has a good chance of using legal action to reverse the decision or at least obtain a substantial settlement, and here again Erichsen is reluctant to introduce any changes in the rules for fear of setting an uncomfortable precedent.

Former East Germans active in the reform process say the problems will persist for decades. "A committee passing out 'certificates of purity' will certainly not solve the problem," says Guntolf Herzberg, a philosophy lecturer at the Free University of Berlin who was expelled from East Germany in 1985. According to Herzberg, the committee's checks will inevitably be superficial because real research into people's backgrounds under the former Communist rule requires "almost detective-style work" based on files that in many cases have disappeared. The problem, he says, parallels that of the larger society: there were an estimated 300,000 people working for the Stasi (secret police), and "you can't lock them all up". Herzberg also fears that harsh legal measures to "filter out the guilty ones" would have severe consequences for a young democracy. Therefore, he says, it is better to give people the benefit of the doubt even when there are strong suspicions against them.

Steven Dickman 